\title{
The Interpretation of Billboards Used in Indonesia And Malaysia: A Semiotic Analysis
}

\author{
Fahrur Rozi ${ }^{1}$, Lulu April Farida ${ }^{2}$, Sulasmianti Samir ${ }^{3}$, Intan Permata Hapsari ${ }^{4}$, \\ Azidan Bin Jabar ${ }^{5}$ \\ \{ozieflu22@gmail.com¹, lulu.a.farida@gmail.com², sulasmianti.samir018@gmail.com³, \\ intan74@mail.unnes.ac.id ${ }^{4}$,azid@upm.edu.my ${ }^{5}$ \} \\ Economic Faculty, Universitas Negeri Semarang ${ }^{1}$, Sport Science Faculty,Universitas Negeri \\ Semarang ${ }^{2}$, Master Program, Universitas Negeri Semarang ${ }^{3}$,
}

\begin{abstract}
This study aimed to interpret billboards used in Malaysia and Indonesia. The method of this study was a qualitative research approach. The objects in this research were billboards that used in Malaysia and Indonesia. The techniques of collecting data were observation and documentation. The data were analysed by using Roland Barthes semiology in order to analyse the signifier and signified of billboards implemented in Malaysia and Indonesia and then to find the meaning of denotation and connotation signs. The result of this study shows that billboards used in Malaysia and Indonesia have some similarities and differences. The similarities and differences can be seen from languages, contents, colours, models, media, designs, and places of billboards.
\end{abstract}

Keywords: Interpretation, Billboards, Semiotic Analysis

\section{Introduction}

In our life, a product or an event needs to be advertised in order to promote it to target or audience. It is called an advertisement. Advertisement is existed in our life. Advertisement uses some languages as a way to convey information. Advertisement is very easy to influence and persuade people to buy or to use the advertised product. It could be through images, texts, or both for delivering the message. Texts in advertisement are used to demonstrate and provide informatoion from the advertised product. Regarding to perception that advertising is one way to promote products, advertising companies make advertisements as attractive as possible.

Nowadays, advertisements become one of crucial points in production field. Companiesor agencies need to make good advertisements to compete with other companies and gain succeessfully. As Jung and Seldon [1] said that success of business much depends on effectiveness of its advertising practices rather than the quality of product itself. Meanwhile, Moriarty said that a unique advertisement is an advertisement that be able to bring new ideas to generate "buzz" so that people will talk about it [Moriarty, 2]. The creativity in advertising is a step forward by the advertiser to encourage the agency to follow the development. In addition, the effective advertisement is advertisement which successfully delivers the message as desired by the advertisers and make a good consumer response. 
There are some media of advertising such as indoor media, outdoor media, online media, offline media, etc. Advertising medium that is installed in open place can be defined as outdoor media. The types of outdoor media are billboards, banners, posters, walls of buildings, bus panels, pedestrian bridges, giant balloons, and so on. Outdoor media is advertisments that can be seen by costumers when their activities are outside of home. Outdoor media is considered to give more impacts because advertisements are very effective and efficient for communicating the message of advertisments in the pluralistic society. All of people can see advertisements as a target of outdoor media of advertising. In addition, advertising by using outdoor media has a reatively long duration, and resistant of weather changes such as rain and heat.

When we talk about outdoor media, the most familiar media is billboard. It is one of the greatest methods to solicit community attention. A Billboard is a big outdoor advertising media which is usually found in high-traffic areas by the side of roads in city. Billboard has been considered as an effective and noticeable advertising medium, especially when the advertiser intends to introduce a new product [Taylor, Franke, \& Bang,3]. As Wysong and Beldona [4] stated that billboards can present products of different involvement level and give a lot of opportunities of companies to advertise a product or an event. Billboards are used to provide, to inform, to educate public about specific site activities and products. They have effectiveness if they reach the intended people. This requires that they present a simple and clear message or symbols in a conspicuous place. As Nyarko, Tsetse, and Avorgah [5] have found out in their study that most respondents view that billboard advertising is a good tool for creating awareness and persuading costumer to choose their appliances. However, billboard designs need to be attractive for the effectiveness because billboard advertising takes at most 2-3 seconds to read one advertisement depend on the direction of costumers on their way [Mitchell: 6]. Similarly, Osborne and Coleman [7] in their study found that smartboards or billboards containing several advertisements with rotation or other kinds of motion caused drivers are difficult to see them because when a driver passes the billboards, he is exposed only to one or two offers from the whole board. For so, billboards should be attractive and effective to reach the public attention. There are some types of billboards based on the purpose of the billboards itself such as: Political billboards; Educational billboards; Medical billboards; Commercial billboards; Drink and food billboards; Household appliance billboards.

With regard to semiotic analysis of billboards, Da Silva [8] has pointed out several features of Nü Green Tea billboard advertisement by dividing some elements: The picture of the bottle with the brand; The brand and the product information/ tagline; The play of colors; and The use of formal and colloquial tagline. In addition, the interaction of those elements is aimed to encourage the main target readership, such as young people, to purchase the product. Meanwhile, Rahmawati, Emzir, and Tajuddin [9] have found that billboards which showed in their research contained the strong persuasive language which combined both of written and visual languages. Hidayat, Nurbani, and Siswanto [10] have taken outdoor media that is billboard as the analysis object in their study. The result of analysis shows that new nuance of Be Marlboro can be used as a reference for advertising tobacco products.

Semiotic is study about signs and how the systems of those signs have a meaning. Semiotic also can be used as the interpretation about the signs. It refers to how meanings are made by persons in texts and cultural practices through linguistic 
and non-linguistic ways. Shortly, semiotic talks about how people understand and how they use sign and symbols to make meaning. Saussure (1857-1913) is known as the fundamental founder in field of semiotics [Ananda: 11]. Ferdinand Saussure defined semiotic is knowledge that studies about the sign as part of social life. He stated that linguistics as a part of semiotics and pointed out that a sign as the combination of "signifier and signified". Signifier refers to something that is in a material form (physical), explicitly existed and can be distinguished by human senses. Meanwhile, signified denotes to something literally and physically does not exist, which is in abstract basis [Yakin \& Totu: 12]. Since it means that the sign in whole is as a result from the associating of the signifier with the signified [Saussure, 13] as shown in the Figure 1as follows:

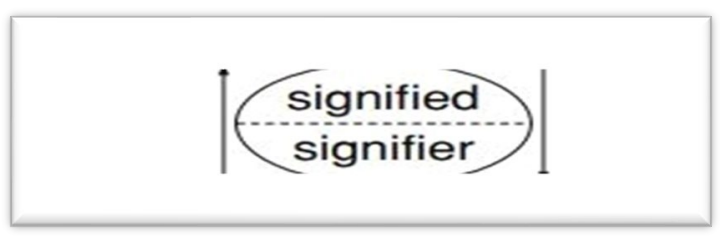

Fig. 1. Saussure's model of sign

In 1915-1980, Roland Gerard Barthes continued and developed Saussure's theory. He pointed out that semiotics explores the study of signs and symbols as a significant part of communication. He stated that semiotic is not only to analyze the signifier and signified but also analyze the relationship which bounded both of them. He is famous for his idea about the denotation and connotation. Denotation refers to the precise, literal definition of a word that might be found in a dictionary, while connotation refers to the wide array of positive and negative associations that most words naturally carry with them. The formula of Barthes' semiotic theory can be seen in the following table:

Signifier

Table 1. Sign Map of Roland Barthes Signified

Denotative Sign

Connotative Signifier

Connotative Signified

Connotative Sign

\section{Method}

This study used qualitative approach. Data were taken from billboards that are used in Malaysia and Indonesia. The data were analysed by using semiotic analysis. The techniques of collecting data were observation and documentation. According to Creswell [15: p.223] a valuable source of information in qualitative data can be documents. The billboards advertised in Malaysia which consist of some types of billboards are compared with billboardsadvertised in Indonesia. Then, the results of the 
comparison were analyzed in order to explore the similarities and the differences. Furthermore, in order to find out the similarities and differences of billboards in Malaysia and Indonesia, researchers used comparative analysis.

\section{Findings and Discussion}

\subsection{Semiotics of Billboards Advertised in Malaysia}

In this study, there are 30 Malaysian billboards which are analysed by using semiotic analysis. The billboards consist of Political billboards, Educational billboards, Medical billboards, Promotion sale billboards, Drink and food billboards, and Household appliance billboards. The semiotic analysis can be seen in the following extracts:

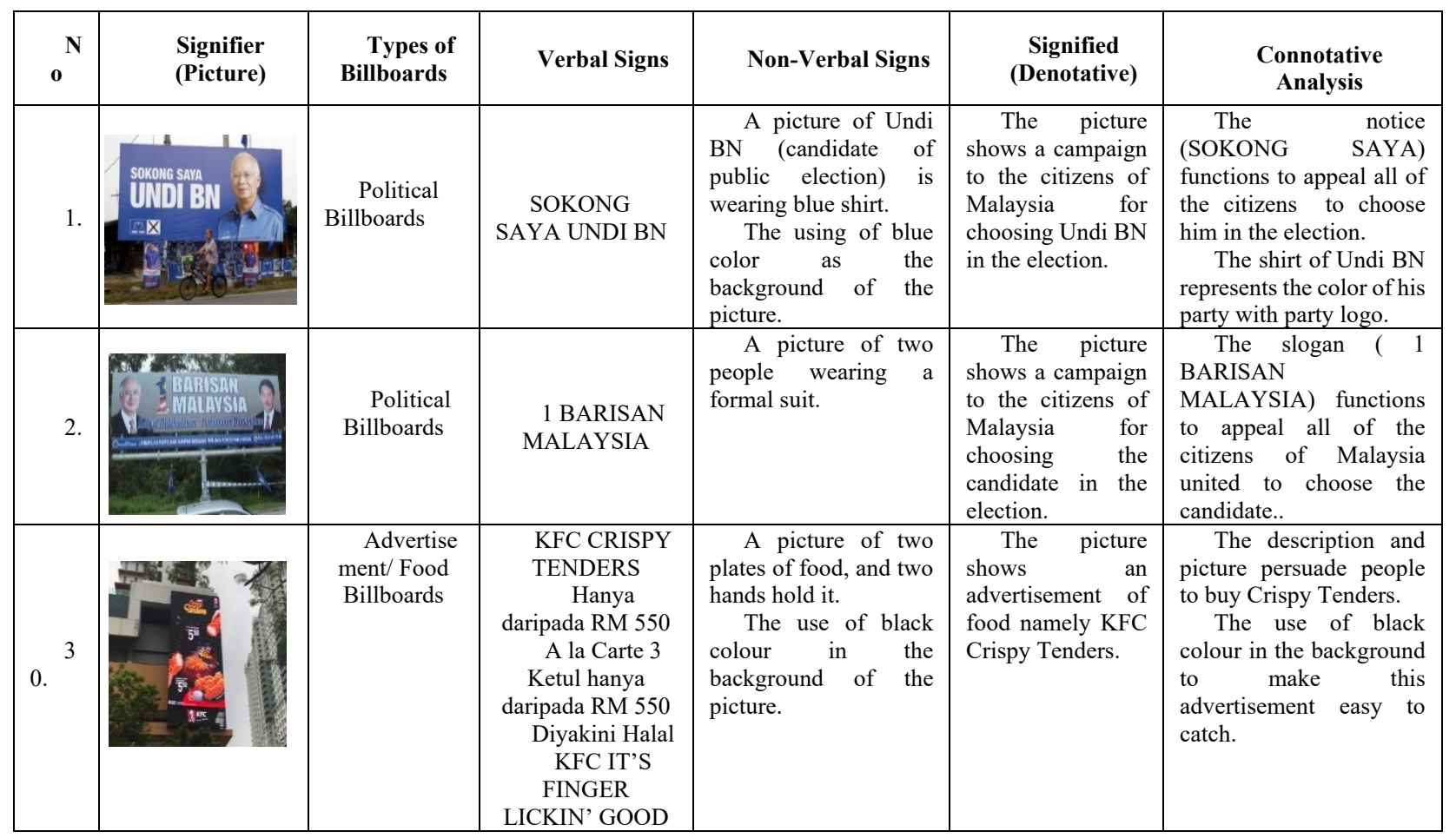

The distribution of billboard types found in Malaysia can be shown in the following table:

Table 2. Finding of billboards in Malaysia

\begin{tabular}{clc}
\multicolumn{2}{c}{ Table 2. } & Finding of billboards in Malaysia \\
\hline No. & Types of Billboards in Malaysia & $\begin{array}{c}\text { Number of } \\
\text { Billboards }\end{array}$ \\
\hline 1 & Political Billboard & 3 \\
2 & Educational Billboard & 3 \\
3 & Medical Billboard & 3 \\
\hline
\end{tabular}




\begin{tabular}{clc}
4 & Promotion Sale Billboard & 3 \\
\hline 5 & Drink and Food Billboard & 12 \\
6 & Household Appliance Billboard & 11 \\
Total & $\mathbf{3 0}$ \\
\hline
\end{tabular}

Based on the table 2 above, Malaysian's billboards are put in visible area where people pass to. All political billboards use background colors based on the basic color of partys they are involved. For instance a billboard uses red color as its background because the character color of this drink namely COCA COLA as shown in the following extract:

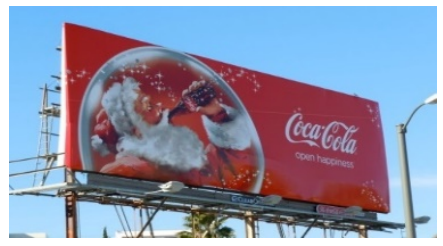

Famous people in billboards can be found in food billboards, beverage billboards, and home appliance billboards. The products and their names display in big size with their slogans. Most of promotion sale billboards in Malaysia are not with part of figures on their billboards. Words and sentences are used to show discount percentages and the events.

\subsection{Semiotics of Billboards Advertised in Indonesia}

There are 30 Indonesian billboards which are analysed by using semiotic analysis. The billboards consist of Political billboards, Educational billboards, Medical billboards, Promotion sale billboards, Food and beverage illboards, Household appliance billboards, Banks Event Billboards, and Music Event Billboards. The semiotic analysis can be seen in the following extracts:

\begin{tabular}{|c|c|c|c|c|c|c|}
\hline $\mathbf{o}^{\mathbf{N}}$ & $\begin{array}{l}\text { Signifier } \\
\text { (Picture) }\end{array}$ & $\begin{array}{c}\begin{array}{c}\text { Types } \\
\text { of } \\
\text { Billboards }\end{array} \\
\end{array}$ & Verbal Sign & $\begin{array}{l}\text { Non-Verbal } \\
\text { Sign }\end{array}$ & $\begin{array}{c}\text { Signified } \\
\text { (Denotative) }\end{array}$ & $\begin{array}{c}\text { Connotative } \\
\text { Analysis }\end{array}$ \\
\hline 1 & 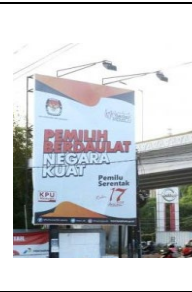 & $\begin{array}{r}\text { Politica } \\
\text { 1 Billboards }\end{array}$ & $\begin{array}{l}\text { PEMILIH } \\
\text { BERDAULAT } \\
\text { NEGARA } \\
\text { KUAT } \\
\text { PEMILU } \\
\text { SERENTAK }\end{array}$ & $\begin{array}{l}\text { A picture of } \\
\text { Komisi Pemilihan } \\
\text { Umum (KPU) logo } \\
\text { with its slogan. } \\
\text { The using of } \\
\text { white and red color } \\
\text { in the background of } \\
\text { the picture. }\end{array}$ & $\begin{array}{l}\text { The picture } \\
\text { shows an appealing } \\
\text { from KPU to the } \\
\text { citizens of Indonesia. } \\
\text { The picture } \\
\text { completed the logo } \\
\text { of KPU and the } \\
\text { notices. }\end{array}$ & $\begin{array}{l}\text { The slogan (PEMILIH } \\
\text { BERDAULAT NEGARA } \\
\text { KUAT) and (PEMILU } \\
\text { SERENTAK) functions to } \\
\text { appeal all of the citizens of } \\
\text { Indonesia to participate the } \\
\text { election. The logo of KPU } \\
\text { represent the color of } \\
\text { Indonesia's flag. }\end{array}$ \\
\hline 2 & (4) & $\begin{array}{c}\text { Politica } \\
\text { 1 Billboards }\end{array}$ & $\begin{array}{l}\text { JOKOWI } \\
\text { ITU.. } \\
\text { KEREEN \& } \\
\text { GAUL } \\
\text { \#2019 Tetap } \\
\text { Jokowi }\end{array}$ & $\begin{array}{l}\text { A picture of } \\
\text { Jokowi (president of } \\
\text { Indonesia) is riding } \\
\text { the motorcycle. }\end{array}$ & $\begin{array}{l}\text { The picture } \\
\text { shows a campaign by } \\
\text { some university } \\
\text { students to choose } \\
\text { Jokowi as the same } \\
\text { president for the next } \\
\text { election. }\end{array}$ & $\begin{array}{l}\text { The slogan (JOKOWI } \\
\text { ITU.. KEREEN \& GAUL) } \\
\text { refers to the style of Jokowi } \\
\text { which is following Dilan's } \\
\text { style (main character in Dilan } \\
1990 \text { film). The film is the hit } \\
\text { at the time. }\end{array}$ \\
\hline
\end{tabular}




\begin{tabular}{|c|c|c|c|c|c|}
\hline 3 & $\begin{array}{c}\text { Food } \\
\text { Billboards }\end{array}$ & $\begin{array}{c}\text { KFC } \\
\text { Holiday Bucket } \\
\text { Diyakini } \\
\text { Halal } \\
\text { KFC It's } \\
\text { Finger Lickin' } \\
\text { Good }\end{array}$ & $\begin{array}{l}\text { A picture shows } \\
\text { a smiley woman with } \\
\text { a hijab holding a } \\
\text { fried chicken with } \\
\text { drinks and food in } \\
\text { front of her. }\end{array}$ & $\begin{array}{l}\text { The picture } \\
\text { shows an } \\
\text { advertisement of a } \\
\text { food and beverages } \\
\text { brand named KFC. } \\
\text { The picture is } \\
\text { completed with } \\
\text { description and logo. }\end{array}$ & $\begin{array}{l}\text { The slogan ( It's Finger } \\
\text { Lickin' Good) functions to } \\
\text { persuade people to buy the } \\
\text { Holiday Bucket menu. }\end{array}$ \\
\hline
\end{tabular}

The distribution of billboard types which are found in Indonesia can be shown in the following table:

\begin{tabular}{clc}
\multicolumn{3}{c}{ Table 3. Finding of billboards in Indonesia } \\
\hline No. & \multicolumn{1}{c}{ Types of Billboards in Malaysia } & $\begin{array}{c}\text { Number of } \\
\text { Billboards }\end{array}$ \\
\hline 1 & Political Billboard & 4 \\
2 & Educational Billboard & 5 \\
3 & Medical Billboard & 3 \\
4 & Promotion Sale Billboard & 3 \\
\hline 5 & Drink and Food Billboard & 7 \\
6 & Household Appliance Billboard & 6 \\
7 & Banks Event Billboard & 2 \\
8 & Music Event Billboard & 1 \\
& Total & $\mathbf{3 0}$ \\
\hline
\end{tabular}

Based on the table 3 above, Indonesian's billboards are located in visible area and people can see the billboards clearly. Political billboards are not designed with official style. The picture is designed with trendy style.

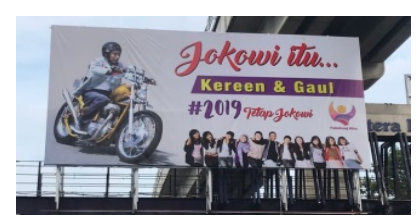

In the political billboard, the candidate does not wear an official suit but he wears casual clothes. Furthermore, the using of agents in billboard can be found in medical billboards, educational billboards, and food billboard. Promotion sale billboards, event and date display in big size in order to attract costumers and they use famous actresses. Most of household appliance billboards in Indonesia are not with part of figures on their billboards. They use words and sentences to persuade customers.

\subsection{The Similarities and Differences of Billboards advertised in Malaysia and} Indonesia

\subsubsection{The Similarities}

The similarities of billboards advertised in Malaysia and Indonesia can be defined from some aspects. Both billboards in Malaysia and Indonesia are placed and displayed in strategic areas. People can see the billboards clearly. It is in line with statement by Siddiqui et.al [16] that billboard is a type of promoting where 
advertisements are put onto huge surface regions to catch people attention. It is placed along thruways and significant city boulevards to get the consideration of drivers and people on foot. For example:

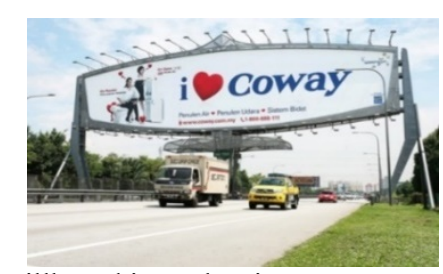

Billboard in Malaysia

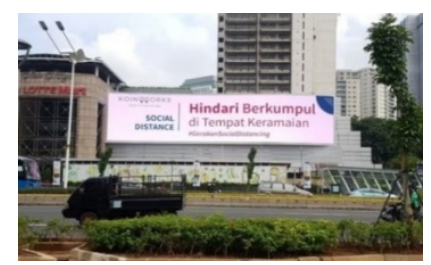

Billboard in Indonesia

Both billboards in Malaysia and Indonesia use background colors which depend on characteristic color of party, food and drink, products, etc. In addition, Shivany [17] stated that the colors used in billboards also reflect another message, besides the language used which also reflects a brief and strong message. Therefore, companies should have unique strategies to capture the customers via creative billboards. For example:

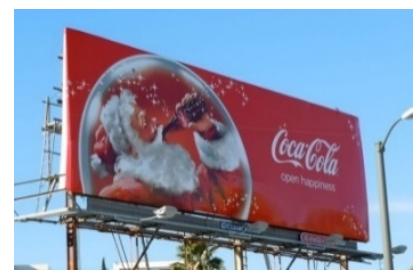

Billboard in Malaysia

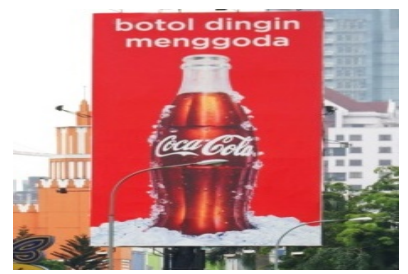

Billboard in Indonesia

Model or people in billboards wear the same color as party, food or product color. For example, the model of billboard in Malaysia picture No.14 (Calpis Fiber) wearing blue clothes just as the characteristic color of the product (blue). Meanwhile, the model of billboard in Indonesia picture No.12 (Shopee) wearing white and orange clothes as same as the characteristic color of the product (white and orange) as follows:

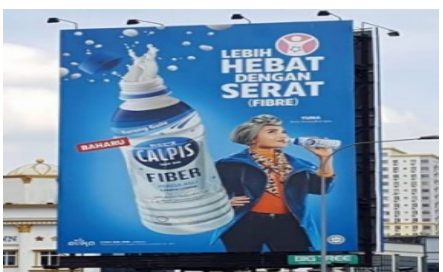

Billboard in Malaysia

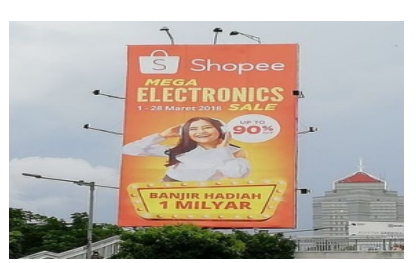

Billboard in Indonesia

\subsubsection{The Differences}

The differences of billboards in Malaysia and Indonesia are identified from some aspects. In particular, Malaysia and Indonesia are a diverse country with various ethnic cultures, languages, and religions. People should consider the use of images in billboards. As Waller and Fam [18] stated that the companies and the marketers must be careful that the content of images in the advertisements will not offend the local community and will be legally allowed to be broadcasted or printed. Furthermore, 
Hussain and Nizamani [19] have revealed that size of boards, colors used in the board, locations and the images selected in the boards does matter for gaining the attentions of the audience/customers. The use of mode in Malaysia billboards can be found in food billboards, drink billboards, and household appliance billboards. Meanwhile, the use of model in Indonesian billboards can be found in medical billboards, educational billboards, and food billboard.

Billboards in Malaysia are designed by using simple sentences for notices and product slogans that are advertised on billboards. On the other side, Indonesian billboards are designed with combination and complex arrangement in sentence structure for notices and product slogans. For instant, drink billboards for Coca-cola, in Malaysian billboard: Coca-cola, Open Happiness (simple and to the point). Meanwhile, in Indonesian billboard: Coca-cola, Botol Dingin Menggoda (longer and complex).
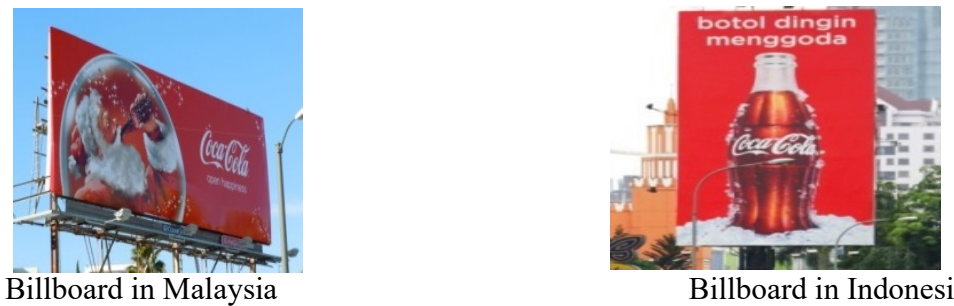

\section{Conclusions}

Billboards advertised in Malaysia and Indonesia give meanings and messages to people. The similarities of billboards between Malaysia and Indonesia can be seen from the placement of the billboards; the using of background color follows the characteristics of the character of the product or event; and the using of clothes of the model in the billboards. Meanwhile, the differences of billboards between Malaysia and Indonesia can be seen from the use of model or public figures in the public notices; and the sentences structure that are used in billboards. Therefore, researchers hope that the finding on this study can be used as a reference by students. The studentsunderstand the meanings of billgboards by using semiotic analysis. Government can use the finding of this study to make a policy for used billboards. For further researchers, the findings need further investigation.

\section{References}

Jung, C.,\& Seldon, B. J. (1995). The Macroeconomic relationship between advertising and consumption,in: Southern Economic Journal.

[2] Moriarty., Sandra., Mitchell, N., \& Wells, W. (2011). Advertising (8th Ed). Volume 1. Translated by: Tri wibowo B S. Jakarta: Kencana Prenada Media Group.

Taylor, C. R., Franke, G. R., \& Bang, H. K. (2006). Use and effectiveness of
billboards: perspectives from selective-perception theory and retail-gravity models. Journal of Advertising, 35(4), 21-34. http:// dx.doi.org/10.2753/JOA00913367350402 .

[4] Wysong. S., \&Beldona, S. (2004). When should a firm use billboard advertising? a conceptual look at different level of recall. Journal of International Business and Entrepreneurship Development, 2(2), 91-98. 
[5] Nyarko, I.K., Tsetse, E.K., \& Avorgah, S.K.M. (2015). .Is Billboard Advertising an Effective Tool in The Marketing of Home Appliances?. Asian Journal of Social Sciences and Management Studies, 2 (3), 101-108, http://www.asianonlinejournals.com/index.php/AJSSMS

[6] Mitchell, M. (2010). An analysis of road signage and advertising from a pragmatic visual communication perspective. Journal of the Australasian College of Road Safety, 21(2), 55-64. http://acrs.org.au/journals/may-2010-vol-21-no-2/.

[7] Osborne. A., \&Coleman, R. (2008). Outdoor advertising recall: a comparison of newer technology and traditional billboards. Journal of Current Issues and Research in Advertising, 30(1), 13-30.

[8] Da Silva, A. M. (2017). A semiotic study of one ready-to-drink tea billboard advertisement in Jakarta. Lingua Cultura, 11(2), 73-77. http://dx.doi.org/10.21512/lc.v11i2.1510.

[9] Rahmawati, L., Emzir, \& Tajuddin, S. (2020). Semiotic analysis and persuasive discourse to the billboardof legislative candidates 2019 in Indonesia. Linguistic, English Education and Art (LEEA) Journal, 3(2), DOI:https://doi.org/10.31539/leea.v3i2.1169.

[10] Hidayat, S., Nurbani, S., \& Siswanto, R.A. (2015). The shifting of cowboy nuance in billboard of marlboro Advertisement of be Marlboro edition. Bandung Creative Movement 2015, 2nd International Conference on Creative Industries.

[11] Ananda, N., S. (2019). Semiotic Analysis on Fast Food Restaurant Advertisements. Surabaya: State Islamic University of Sunan Ampel.

[12] Yakin, H., S., M and Totu, A. (2014). The semiotic perpectives of Peirse and Saussure: A brief comparative study. Procedia - Social and Behavioral Sciences, 155, 4-8.

[13] Saussure, F. de. (1959). Course in general linguistics (W. Baskin, Trans.). New York: Phil. Libr.

[14] Chandler, D. (2007). Semiotics the Basics Second Edition. London: Routledge.

[15] Creswell, J., W. (2012). Educational Research Planning, Conducting and Evaluating Quantitative and Qualitative Research 4th Edition. Lincoln: University of Nebraska.

[16] Siddiqui, K.A., Tarani, S.S.A., Fatani, S.A., Raza, A., Butt, R.M.,\&Azeema, N. (2016). Effect of size, location and content of billboards on brand awareness.Journal of Business Studies Quarterly, 8 (2).

[17] Shivany, S. (2018). Billboard advertisement strategies. International Journal of Application or Innovation in Engineering \& Management (IJAIEM). 7(4), Website: www.ijaiem.org.

[18] Waller, D.S.,\& Fam, K.S. (2014). Cultural values andadvertising in Malaysia: views from the industry. Asia Pacific Journal of Marketing and Logistics. DOI: 10.1108/13555850010764613.

[19] Hussain, J., \& Nizamani, R. K. (2011). Factors affecting consumer attention in billboards advertising. South Asian Journal of Management Sciences , 5 (2), 60-64. 